\title{
Genetic signals of historic and recent migration between sub-populations of Atlantic walrus Odobenus rosmarus rosmarus west and east of Greenland
}

\author{
L. W. Andersen ${ }^{1, *}$, E. W. Born ${ }^{2}$, D. W. Doidge ${ }^{3}$, I. Gjertz ${ }^{4}$, Ø. Wiig ${ }^{5}$, R. S. Waples ${ }^{6}$ \\ ${ }^{1}$ National Environmental Research Institute and University of Aarhus, Department of Wildlife Ecology and Biodiversity, \\ Grenåvej 12, 8410 Rønde, Denmark \\ ${ }^{2}$ Greenland Institute of Natural Resources, PO Box 570, 3900 Nuuk, Greenland \\ ${ }^{3}$ Nunavik Research Centre, Makivik Corporation, PO Box 179, Kuujjuaq, Québec JOM 1CO, Canada \\ ${ }^{4}$ The Research Council of Norway, PO Box 2700 St. Hanshaugen, 0131 Oslo, Norway \\ ${ }^{5}$ Natural History Museum, University of Oslo, PO Box 1172 Blindern, 0318 Oslo, Norway \\ ${ }^{6}$ Northwest Fisheries Science Center, National Marine Fisheries Service, Seattle, Washington 98112, USA
}

\begin{abstract}
Defining sub-populations and determining migration rates between them is crucial for sound management and conservation. This also applies to the Atlantic walrus Odobenus rosmarus rosmarus, which is still exploited although population levels are low in some cases and information on abundance is lacking in others. Analysis of muscle and skin tissues using 11 nuclear microsatellite markers from a total of 297 Atlantic walruses from the Hudson Strait across W, NW and E Greenland to Svalbard and Franz Josef Land was undertaken to determine the number of sub-populations, their ancestral origin and the contemporary rates and directions of migration (gene flow) between the various areas. The study indicated the existence of 5 sub-populations in the Hudson Strait, W Greenland, NW Greenland, E Greenland and Franz Josef Land-Svalbard. Identification of the Hudson Strait subpopulation was novel; although differences between animals here and in W Greenland were small, they were statistically significant and indicated that walruses in the Hudson Strait could be a population source for walruses for the W Greenland sub-population. The direction of migration (Hudson Strait to W Greenland) suggested a genetic signal from a historical large-scale counter-clockwise perennial migration pattern in the Baffin Bay region. The study provides essential information on population sub-structuring that is a prerequisite for management of Atlantic walruses at sustainable levels.
\end{abstract}

KEY WORDS: Odobenus rosmarus rosmarus · Greenland · Microsatellites · Population structure · Migration direction

Resale or republication not permitted without written consent of the publisher

\section{INTRODUCTION}

\section{Conservation concerns}

Throughout their range, Atlantic walruses Odobenus rosmarus rosmarus have been heavily exploited, causing reductions in range and number compared to recent historical times (Born et al. 1995). In many parts of Canada and Greenland, estimates of abundance do not exist or are merely educated guesswork. Several populations are thought to number less than a few thousand individuals (COSEWIC 2006, NAMMCO 2006).

Currently, Atlantic walruses are hunted by Inuit in Canada throughout the south and east Hudson BayHudson Strait and in W, NW and E Greenland. Exploitation rates in W and NW Greenland are thought to be unsustainable (Born et al. 1994, 1995, Anonymous 1995, Witting \& Born 2005, COSEWIC 2006, NAMMCO 2006), emphasising the importance of sub- 
population recognition and identification of migration rates (gene flow) and their directions.

In 2006, Atlantic walruses in Canada, including 2 shared sub-populations in W and NW Greenland, were designated 'species of special concern' by the Committee on the Status of Endangered Wildlife in Canada (COSEWIC). The assessment concluded that the species is near to qualifying for threatened status and requires an effective plan for management of exploitation (COSEWIC 2006). COSEWIC defines a 'species of special concern' as a "species that might become threatened or endangered" based on a combination of biological and other identified threats; 'threatened' implies that a species is likely to become 'endangered' facing imminent extirpation or extinction if limiting factors are not moderated or removed (COSEWIC 2006).

Historically, walruses were heavily exploited in the Svalbard and Franz Josef Land areas, causing a serious decline in numbers. As a result, walruses were fully protected in these areas in 1952 and 1956, respectively, and have been protected there ever since (cf. Gjertz \& Wiig 1994, Born et al. 1995). However, in recent years there have been signs of recovery in this population, and a survey in 2006 suggested that there were ca. 2600 walruses in the Svalbard area alone (NAMMCO 2006, Lydersen et al. 2008).

To ensure sustainability, it is common practice to manage large Arctic marine mammals at the sub-population level (e.g. polar bears Ursus maritimus, Aars et al. 2006; beluga Delphinapterus leucas, Alvarez-Flores \& Heide-Jørgensen 2004; narwhal Monodon monoceros, Anonymous 2005). Information on the geographical distribution, genetic identity and number of subpopulations and rates of exchange of individuals between them is therefore crucial.

Recent and historical migration patterns between populations are important factors in shaping the contemporary genetic population structure (Ramstad et al. 2004). The existence of several sub-populations or stocks of Atlantic walruses has been suggested (Born et al. 1995, NAMMCO 1995, 2006). However, in several cases, our knowledge of the sub-structure of these populations is insufficient to be able to assess them separately (COSEWIC 2006). We analysed the population structure and migration between groups of walruses in the Hudson Strait area, W, NW and E Greenland, Svalbard and Franz Josef Land (see Table 1, Fig. 1).

\section{Background}

To understand the background to the present study, it is important to describe some life history characteristics of walruses and the ecological situation in the Baf- fin Bay region where walruses are exploited by Canadian and Greenlandic Inuit.

\section{Life history characteristics}

Walruses have life history traits typical of large mammals. They are relatively long lived, grow slowly and show delayed onset of sexual maturity. They produce few offspring per cycle but invest heavily in each of their young (Fay 1982). Average age at attainment of sexual maturity (first ovulation) in female Atlantic walruses in Greenland is around $6 \mathrm{yr}$, so first births occur at ca. $7 \mathrm{yr}$ of age (Born 2001). The generation time (defined as the mean age of mothers producing offspring in a given year) in walruses is close to $15 \mathrm{yr}$ (i.e. between sexual maturity and age at reproductive senescence: 25 to $30 \mathrm{yr}$, Fay 1982). The reproductive cycle is basically triennial; adult females give birth every third year, usually to a single calf (Fay 1982, Born 2001). Male Atlantic walruses become sexually mature between 7 and $17 \mathrm{yr}$ of age (average: $11 \mathrm{yr}$, Born 2003). However, Pacific walruses Odobenus rosmarus divergens usually do not participate in mating until physically mature at 13 to 16 yr (Fay 1982), and the same is probably the case in Atlantic walruses.

Atlantic walruses occupy a large geographical range but a relatively narrow ecological niche. They require shallow waters with bottom substrates that support productive bivalve communities, which retain open water above feeding areas in winter, and suitable ice or land nearby upon which to haul out (COSEWIC 2006). Walruses show a high degree of fidelity to such foraging sites (e.g. Born et al. 1997). Female walruses are found in polynyas or similar geographically restricted open water areas surrounded by ice during the mating season (e.g. Sjare \& Stirling 1996), which peaks in January to April (Fay 1982, Fay et al. 1984, Born 2001). The generally sedentary nature of walruses during winter and the inherent gregariousness of females appear to have been important factors influencing the evolution of the species' social behaviour and mating system (Sjare \& Stirling 1996). These factors are also likely driving forces behind the establishment of genetically different sub-populations of Atlantic walruses.

\section{Possible migration patterns between areas}

Historically, walruses in the Baffin Bay region seem to have been more numerous and more widely distributed than at present (Freuchen 1921, Vibe 1950). It has been suggested that walruses made large-scale, counter-clockwise perennial migrations in the Baffin 
Bay region between Canada (i.e. East Ellesmere Island and East Baffin Island and the Hudson Strait areas) and W and NW Greenland (Freuchen 1921, Vibe 1950). This suggestion was based on timing of the presence in near-shore areas as well as timing of ice breakup in different areas. The timing of catches indicated that when walruses left their wintering grounds in central W Greenland in spring, they migrated north along the western coast of Greenland to the North Water area (i.e. northern Baffin Bay-Smith Sound), where a portion of the population had overwintered. This northward migration in spring was possible because ice break up occurs relatively early along the western coast of Greenland due to the influx of relatively warm water from the Irminger Current in the south (e.g. Born \& Böcher 2001). During fall, the formation of sea ice develops from west towards the east (i.e. from Baffin Island towards western Greenland). Hence, the appearance of walruses along eastern Baffin Island in late summer and their reappearance in fall in central W Greenland supported (1) the theory of a counter-clock overall migration pattern in the Baffin Bay area, and (2) the theory that this migration was determined by the timing of ice break up and ice formation in the region (Freuchen 1921, Vibe 1950). However, over-exploitation seemed to cause walrus numbers to decline throughout their range (Born et al. 1995 and references therein). Mansfield (1973) noted the absence of reports of any large-scale migrations in the Baffin Bay region during the second half of the 20th century. He hypothesised that the decline in numbers and the innate dependence of walruses on sessile food resources in localised shallow coastal waters had made walruses more sedentary in the Baffin Bay-Davis Strait region (Vibe 1950, Fay 1982).

\section{Objectives}

The present study aimed to provide information on population sub-structure necessary for management of Atlantic walruses at sustainable levels. The objectives were (1) to estimate the number of sub-populations that are represented in a combined sample from parts of the range of Atlantic walruses, (2) to analyse the historical and contemporary migration patterns within and between sub-populations, and (3) to determine the historical and contemporary effective population size. Objective 2 evaluates the hypotheses of enhanced sedentary contemporary behaviour, and the presumed historical counter-clockwise migration, in the Baffin Bay region between eastern Canada and western Greenland, and Objective 3 could indicate whether the different sub-populations had experienced a population bottleneck.

\section{MATERIALS AND METHODS}

Samples. Samples of tongue tissue from 58 Atlantic walruses from the Hudson Strait (12 from the eastern and 54 from the western Hudson Strait; Fig. 1) were collected by Canadian Inuit from their subsistence catch during 1998 to 2000 . The samples were frozen at $-20^{\circ} \mathrm{C}$ until analysed in the laboratory of the National Environmental Research Institute (Silkeborg, Denmark). The samples included information on the site of the catch and/or the name of the community to which the sample was delivered (for regions, stocks, sample size and abbreviations see Table 1). The samples from Canada are referred to as Hudson Strait in the following as there was no significant genetic difference between the 2 sampling areas (i.e. western and eastern Hudson Strait) (data not shown).

Walruses from central W, NW and E Greenland, Svalbard and Franz Josef Land have previously been genetically analysed (Andersen et al. 1998, Andersen \& Born 2000, Born et al. 2001). The previous E Greenland sample of 28 ind. was supplemented with a further 48 ind. These 48 specimens were not genetically different from the previously analysed E Greenland samples $\left(F_{\mathrm{ST}}=\right.$ 0.003, 95\% CI: -0.001 -0.006; FSTAT, Goudet 1995) based on the 11 microsatellite markers used in the present study (Hg 6.1, ORR7, ORR3, SGPV9, HGDii, ORR24, ORR23, Igf-1, ORR11,ORR9, ORR16; Andersen et al. 1998); hence all E Greenland data were pooled (Table 1).

All analyses were conducted using $N$, the number of individuals actually sampled at the different sampling locations, except for the estimation of $\mathrm{N}\left(\mathrm{N}_{\mathrm{e}}\right)$ where adjusted sample size $\left(\mathrm{N}^{* *}\right)$ was used (Table 1$)$.

DNA was extracted from the Hudson Strait and the recent E Greenland samples using a modified CTABbuffer method (Milligan 1992) including Proteinase K. The 11 microsatellite primers used and their PCR conditions are given in Andersen et al. (1998) and Andersen \& Born (2000). PCR products were electrophoresed using an ABI PRISM 377 DNA sequencer and subsequently genotyped.

The gender of the samples from the Hudson Strait, E Greenland and Franz Josef Land lacking phenotypic information on sex was determined using a sex-specific primer set for walrus (Fischbach et al. 2008). For numbers of males, M, and females, F, see Table 1.

Data analyses. Genetic variation was estimated as observed and expected heterozygosity and allele richness in FSTAT (Goudet 1995). Tests for goodness of fit to Hardy-Weinberg expectations (HWE) were performed in GENEPOP (Raymond \& Rousset 1995). Significance levels were computed using Fisher's exact test (Guo \& Thompson 1992). Tests for linkage disequilibrium between all pairs of loci were conducted for separate samples and analysed in FSTAT (Goudet 1995). 


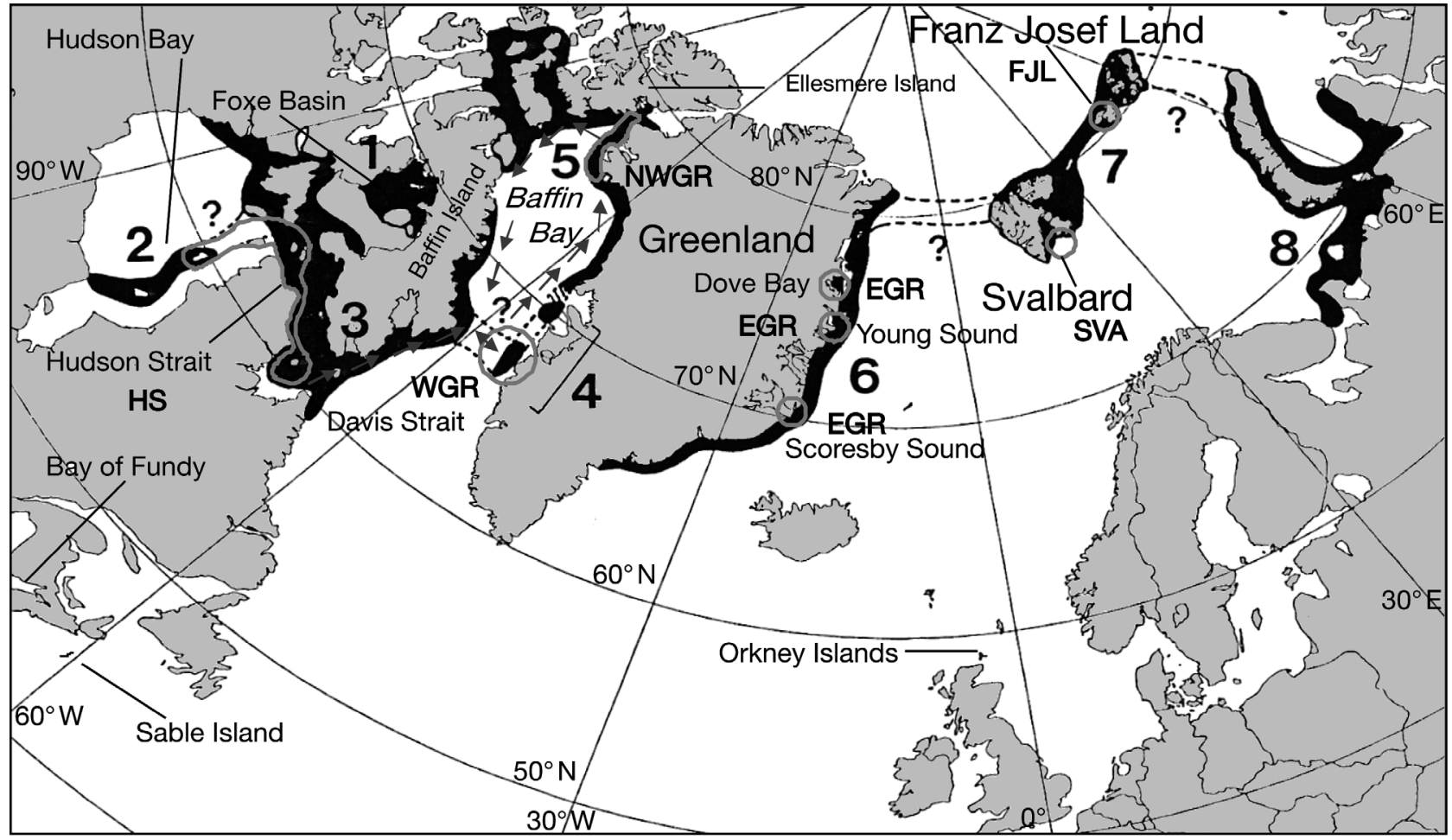

Fig. 1. Odobenus rosmarus rosmarus. Approximate distribution of Atlantic walrus sub-populations (after Born et al. 2001). Samples included in the present study came from areas inhabited by the putative stocks numbered 2,3,4,5,6 and 7. Grey lines delineate sampling sites, arrows show the described counter-clockwise migration movements of walruses west of Greenland, and question marks and dashed black lines show possible connection routes between sub-populations. For abbreviations of region see Table 1

Table 1. Odobenus rosmarus rosmarus. Summary of samples used for genetic analysis from eastern Canada, Greenland and Franz Josef Land and Svalbard. Putative stock numbers from Born et al. (1995) and Fig. 1. The Foxe Basin sub-population was recognised by Born et al. (1995) but was not included in the present study. F: female; M: male; 4 individuals in W Greenland were not sexed. Adjusted sample sizes $\left(\mathrm{N}^{* *}\right)$ are after identification of migrants and replacing those individuals to the identified origin (see 'Materials and Methods' for details); (-) no data available

\begin{tabular}{|c|c|c|c|c|c|c|c|}
\hline Region & Abbreviation & $\begin{array}{c}\text { Putative stock } \\
\text { no. }\end{array}$ & $\mathrm{N}$ & $\mathrm{F}$ & M & $\mathrm{N}^{* *}$ & Sampling year \\
\hline Foxe Basin & - & 1 & - & - & - & - & \\
\hline Northwest Greenland & NWGR & 5 & 72 & 29 & 43 & 59 & $1990,1991^{a}$ \\
\hline West Greenland & WGR & 4 & 33 & 18 & 11 & 16 & $1988,1989,1997^{\mathrm{a}}$ \\
\hline Hudson Strait & HS & 3 & 58 & 16 & 42 & 64 & New material 1998-2000 \\
\hline East Greenland & EGR & 6 & 76 & - & 76 & 74 & $\begin{array}{c}1989,1990^{\mathrm{a}} \\
\text { New material } 1999-2000\end{array}$ \\
\hline Svalbard & SVA & 7 & 28 & - & 28 & $56^{\mathrm{b}}$ & $1992^{\mathrm{a}}$ \\
\hline Franz Josef Land & FJL & 8 & 30 & 16 & 14 & $56^{\mathrm{b}}$ & $1992^{\mathrm{a}}$ \\
\hline Total & & - & 297 & 79 & 214 & - & \\
\hline
\end{tabular}

Estimation of the number of sub-populations (Objective 1). We re-analysed the walrus data of Andersen et al. (1998), Andersen \& Born (2000) and Born et al. (2001) (i.e. NW, W and E Greenland plus new data, Svalbard and Franz Josef Land), supplemented with the Hudson Strait sample. The degree of population differentiation was analysed using unbiased $F_{\mathrm{ST}}$ statistics (Weir \& Cockerham 1984) performed in FSTAT (Goudet 1995) and based on sampling locations. Furthermore, we pooled samples from all areas and evaluated assumptions that they originated from 2 to 8 sub-populations without using prior 
information of sample origin. The most likely number of sub-populations was estimated using a Bayesian clustering method that groups individuals so as to minimise Hardy-Weinberg disequilibrium and gametic phase disequilibrium within groups, as implemented in STRUCTURE (Pritchard et al. 2000). We used 1000000 iterations of a Markov Chain Monte Carlo (MCMC) search algorithm with burn-in of 100000 and 2 runs. For each number of postulated populations $(k)$, STRUCTURE finds the optimal partitioning of individuals into $k$ groups and, for each individual, estimates the proportion of its genes $\left(q_{k}\right)$ that are derived from each of the $k$ sources.

Estimation of historical and contemporary migration patterns (Objective 2). The historical migration pattern and long-term effective population size was estimated in MIGRATE (MIGRATE 2.1.0, available at: http://popgen.csit.fsu.edu/migrate.download.html; Beerli \& Felsenstein 2001, Beerli 2006) using the likelihood approach. The method assumes that the population sizes and migration rate between pairs of populations were constant over the coalescence period (about $4 N_{e}$ generations; Austin et al. 2004). MIGRATE uses estimates of gene genealogies to sample areas of the coalescence space with highest likelihoods. MIGRATE was run according to the authors' recommendations. The random number of seed and starting values of $\theta$ and $4 N_{\mathrm{e}} m$ (where $N_{\mathrm{e}} \mathrm{m}$ is the indirect measure of gene flow) were based on $F_{\mathrm{ST}}$, and the subsequent run used the $\theta$ and $4 N_{e} m$ from previous runs as starting parameters (Beerli 2006). A Brownian mutation model was assumed, and the data were analysed using 10 short $\left(10^{4}\right.$ MCMC steps) and 5 long chains ( $10^{5} \mathrm{MCMC}$ steps), together with 'adaptive heating' based on 4 temperatures, 1 'cold' and 3 'hot' chains to assure convergence.

To estimate the direction and rate of contemporary migration over the most recent generations and migrant ancestries, a Bayesian method based on multilocus genotypes implemented in BAYESASS was used (BAYESASS, Wilson \& Rannala 2003). The method does not assume that populations are at genetic equilibrium or that genotypes are in accord with HardyWeinberg equilibrium, but the loci in the parent populations are assumed to be in linkage equilibrium. The method is based on MCMC methods to estimate the posterior probabilities of the migration matrix among sub-populations (Wilson \& Rannala 2003). Convergence was achieved after $6 \times 10^{6} \mathrm{MCMC}$ iterations and a burn-in of $2 \times 10^{6}$ steps. The data were run 3 times, and the run in which the log-likelihood had peaked and with the highest log-likelihood was chosen.

Isolation by distance was estimated using geographical distances measured between the cores of the distribution areas of the populations in question using the shortest straight-line distance. The relationships between the genetic and geographical distances among the populations were estimated using a Mantel test implemented in ARLEQUIN v. 2.0 (Schneider et al. 2000).

Historical and contemporary effective population size (Objective 3). The heavy exploitation by sealers during the 18th, 19th and early 20th centuries in some areas (Born et al. 1995) could have caused a significant reduction in genetic variation of walruses. Therefore, we tested for bottleneck effect in all sampling areas using the M-ratio (Garza \& Williamson 2001) and BOTTLENECK 1.2 (Piry et al. 1999). The M-ratio contrasts the number of alleles, $k$, and the overall range in allele size, $r_{i}$ when population size declines, the number of alleles drops faster than the range, leading to smaller $M$ values The parameters used in the present study were $p_{s}$ (percent 1-step mutations) $=80 \%(90 \%), \Delta_{g}$ (mean size of non 1-step mutations) $=3.5$ and $\mu=5 \times$ $10^{-4}$ as recommended by Garza \& Williamson (2001). Historical effective population size $(\theta)$ was estimated from MIGRATE (Beerli \& Felsenstein 2001, Beerli 2006; see above), while contemporary $\mathrm{N}_{\mathrm{e}}$ was obtained from a linkage disequilibrium method (Hill 1981, Waples 2006; see below). In contrast to the $M$-ratio, BOTTLENECK 1.2 (Piry et al. 1999) is designed to detect an incompatibility between heterozygosity and the number of alleles per locus; following a decline in population size, the reduction in allele numbers occurs faster than the loss of heterozygosity, resulting in an apparent heterozygosity excess (Nei et al. 1975, Cornuet \& Luikart 1996).

To evaluate the performance of BOTTLENECK we used EASYPOP v.1.7 (Balloux 2001) to simulate isolated populations segregating for 11 variable loci (as in our data) following a $k$-allele mutation model (each mutation equally likely to lead to any of $k$ allelic states) and mutation rate $\mu=5 \times 10^{-4}$. Each replicate population ran for 5000 to 10000 generations to reach mutation-drift equilibrium before sampling. First, a single panmictic population with $\mathrm{N}_{\mathrm{e}}=10000$ was simulated. After reaching mutation-drift equilibrium, the population was split into 50 sub-populations each having $\mathrm{N}_{\mathrm{e}}=$ 200 and tested in BOTTLENECK. The bottleneck size $\left(\mathrm{N}_{\mathrm{e}}=200\right)$ was maintained for 50 generations, at which time 50 ind. were sampled from each population and tested in BOTTLENECK. This procedure was repeated with bottleneck size $\mathrm{N}_{\mathrm{e}}=1000$ and with a constant $\mathrm{N}_{\mathrm{e}}=$ 10000 (as a control; no bottleneck).

Under the assumption of the 2-phase mutation model (TPM; Di Rienzo et al. 1994) allowing for 90\% singlestep mutations and $10 \%$ multi-step mutations and a variance of $12 \%$, the test for bottleneck was performed using the Wilcoxon test implemented in the program BOTTLENECK v. 1.2 (Piry et al. 1999). This test evaluates whether the number of loci with heterozygote ex- 
cess is larger than expected to occur by chance alone; it is non-parametric, so is better suited for our analyses involving 11 loci than the standardized differences test also available under BOTTLENECK, which ideally requires 20 or more loci (G. Luikart pers. comm.).

The historical effective population size was estimated using the coalescence approach in MIGRATE (Beerli 2006) as described under Objective 2. Recent effective population size was estimated using the linkage disequilibrium method, which depends on random associations of alleles at different gene loci. The squared correlation of allele frequencies at pairs of loci $\hat{r}^{2}$ was calculated using the composite Burrows method. This method, which is simpler than maximumlikelihood methods and does not require the assumption of random mating, is the preferred method for use with genotypic data such as are available for this study (Weir 1996). To estimate $\hat{N}_{e}$ from $\hat{r}^{2}$ we used the program LDNe (Waples \& Do 2008), which implements the bias correction method described by Waples (2006). To minimise possible bias from low frequency alleles, we only used alleles with a frequency $\geq 0.02$; this criterion appears to provide a good balance between maximising precision and minimising bias with highly polymorphic loci like microsatellites (Waples \& Do 2008 and unpubl. data). Confidence intervals to $\hat{N}_{e}$ were computed using Eq. (12) in Waples (2006).

As the LDNe method can be biased by population mixture, we used STRUCTURE, BAYESASS and GENECLASS 2 (Piry et al. 2004) to identify migrants. Individuals identified as migrants by at least 2 of the assignment methods were moved to the identified area of origin before estimating the effective population size. Hence, the sample sizes in some areas decreased, but increased in others (Table 1). In GENECLASS v. 2 (Piry et al. 2004), the likelihood of an individual's genotype was estimated using $L=L_{\mathrm{HOME}} / L_{\mathrm{MAX}}$ (Paetkau et al. 2004) and the Bayesian computation criteria of Rannala \& Mountain (1997). Significance of the assignment of individuals at the $5 \%$ level was assessed based on the MCMC resampling option described by Paetkau et al. (2004). GENECLASS was only used to identify migrants for the replacement to other areas.

The sequential Bonferroni procedure was applied in table-wide tests of HWE, $F_{\mathrm{ST}}$, number of loci with significant different allele distribution and bottleneck at the $5 \%$ significance level (Rice 1989).

\section{RESULTS}

After application of the sequential Bonferroni procedure (Rice 1989) no overall deviations from the HWE were observed in the Hudson Strait sample (Table 2). No linkage disequilibrium was observed between all
Table 2. Odobenus rosmarus rosmarus. Expected $\left(H_{\mathrm{e}}\right)$ heterozygosity, allele richness (AR) and goodness of fit to the Hardy-Weinberg expectations (HWE; $F_{\mathrm{IS}}$ ) testing for heterozygosity deficiency in GENEPOP (Raymond \& Rousset 1995) at 11 microsatellite loci (Andersen et al. 1998) for walrus samples from 6 different areas. ${ }^{*}$ : significant deviation from HWE at Orr11; ${ }^{* *}$ : significant deviation from HWE at Orr16 and overall

\begin{tabular}{|lccccl|}
\hline & $H_{\mathrm{e}}$ & $\mathrm{SD}$ & $\mathrm{AR}$ & $\mathrm{SD}$ & $F_{\mathrm{IS}}$ \\
\hline NW Greenland & 0.647 & 0.056 & 6.55 & 2.63 & $0.055^{*}$ \\
W Greenland & 0.608 & 0.093 & 6.06 & 3.07 & 0.058 \\
Hudson Strait & 0.614 & 0.066 & 5.95 & 3.01 & 0.032 \\
E Greenland & 0.59 & 0.079 & 5.02 & 1.98 & 0.021 \\
Svalbard & 0.658 & 0.078 & 6.18 & 3.54 & $0.118^{* *}$ \\
Franz Josef Land & 0.634 & 0.09 & 6.05 & 2.78 & 0.088 \\
\hline
\end{tabular}

pairs of loci within the different sampling areas (data not shown), hence the prior assumptions regarding linkage equilibrium in the parent populations behind the method implemented in STRUCTURE (Pritchard et al. 2000) are not violated.

\section{Estimation of the number of sub-populations (Objective 1)}

All $F_{\mathrm{ST}}$ estimates from the pairwise comparisons (except Franz Josef Land-Svalbard) revealed significant differences among the 6 sampling areas (Table 3). The pairwise $F_{\mathrm{ST}}$ estimates over all loci ranged from 0.021 between the Hudson Strait and W Greenland samples to 0.069 between the Hudson Strait and NW Greenland samples (Table 3).

The STRUCTURE analysis found by far the strongest support for the existence of 5 genetically distinct sub-populations: Hudson Strait, W, NW and E Greenland and Franz Josef Land-Svalbard (ln probability of data ln $\mathrm{P}$ [D]: $k=4, \ln =-9506.6 ; k=5$, $\ln =-9327.8 ; k=6, \ln =-9652.23 ;$ Fig. 2). Under the assumption that $k=5$, the clusters identified by STRUCTURE largely corresponded to the 5 sampling locations identified as distinct in the $F_{\mathrm{ST}}$ analyses: (E Greenland, W Greenland, NW Greenland, Hudson Strait and Franz Josef Land-Svalbard; Table 4, Fig. 2). STRUCTURE was not able to identify a separate Franz Josef Land and Svalbard sub-population for higher numbers of clusters $(k)$.

The low $F_{\text {ST }}$ estimate between the Hudson Strait and W Greenland suggests that these 2 groups of walruses might have diverged recently or are still exchanging migrants. A crude estimate of the time for divergence ( $t$, in generations) between W Greenland and the Hudson Strait based on the $F_{\mathrm{ST}}$ can be obtained from the expectation that $t \approx 2 \mathrm{~N}_{\mathrm{e}} F_{\mathrm{ST}}$ (Hartl \& Clark 1997). 
Table 3. Odobenus rosmarus rosmarus. Results of the pair-wise multilocus $F_{\mathrm{ST}}$ tests and the $95 \%$ confidence intervals (in parentheses) for genetic differences between 5 putative sub-populations of Atlantic walrus from the Hudson Strait region, NW Greenland, W Greenland, E Greenland and the Franz Josef Land-Svalbard area. All tests performed in FSTAT after 10000 permutations (Goudet 1995). Values in bold are significant

\begin{tabular}{|c|c|c|c|c|c|}
\hline & NW Greenland & W Greenland & Hudson Strait & E Greenland & Svalbard \\
\hline W Greenland & $\begin{array}{c}0.035 \\
(0.021-0.052)\end{array}$ & & & & \\
\hline Hudson Strait & $\begin{array}{c}0.043 \\
(0.025-0.058)\end{array}$ & $\begin{array}{c}0.021 \\
(0.009-0.036)\end{array}$ & & & \\
\hline E Greenland & $\begin{array}{c}0.069 \\
(0.039-0.112)\end{array}$ & $\begin{array}{c}0.048 \\
(0.027-0.068)\end{array}$ & $\begin{array}{c}0.066 \\
(0.044-0.091)\end{array}$ & & \\
\hline Svalbard & $\begin{array}{c}0.060 \\
(0.037-0.086)\end{array}$ & $\begin{array}{c}0.041 \\
(0.019-0.068)\end{array}$ & $\begin{array}{c}0.037 \\
(0.019-0.060)\end{array}$ & $\begin{array}{c}0.054 \\
(0.048-0.094)\end{array}$ & \\
\hline Franz Josef Land & $\begin{array}{c}0.046 \\
(0.030-0.065)\end{array}$ & $\begin{array}{c}0.027 \\
(0.012-0.042)\end{array}$ & $\begin{array}{c}0.034 \\
(0.021-0.050)\end{array}$ & $\begin{array}{c}0.037 \\
(0.020-0.054)\end{array}$ & $\begin{array}{c}0.024 \\
(-0.005-0.063)\end{array}$ \\
\hline
\end{tabular}

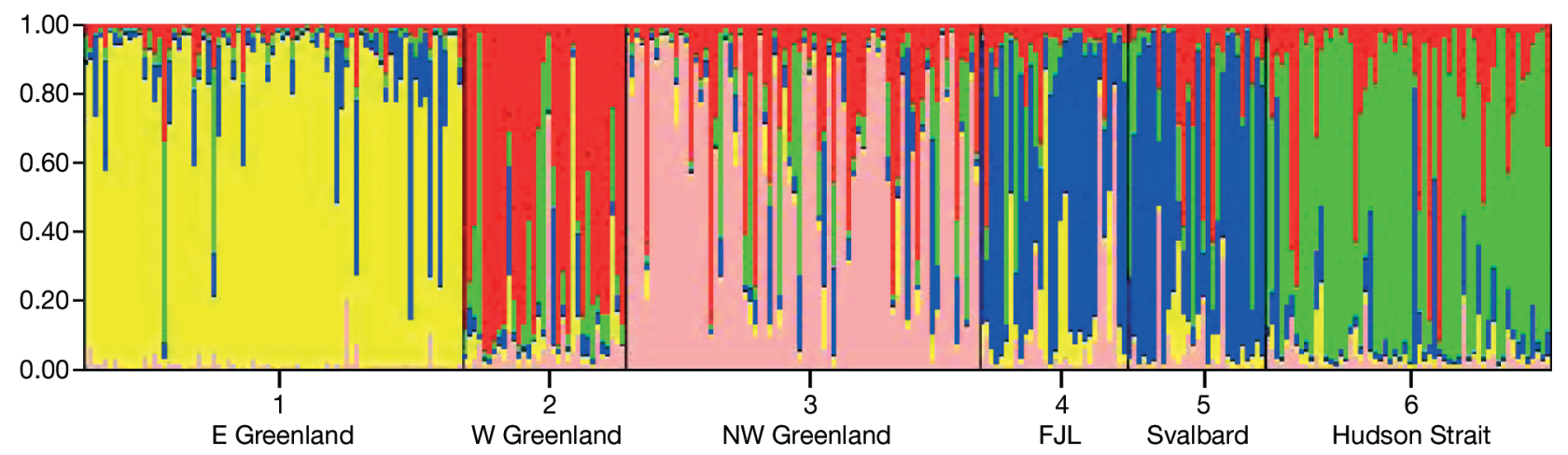

Fig. 2. Odobenus rosmarus rosmarus. Graphical output from STRUCTURE (Pritchard et al. 2000) for number of suggested populations, $k=5$. Each vertical line represents an individual, and the colour composition displays the probability of belonging (proportion of membership) to each of the 5 clusters defined by STRUCTURE. FJL: Franz Josef Land

Table 4. Odobenus rosmarus rosmarus. Mean estimated proportion of membership (q) of the individuals into 1 of the 5 identified clusters in Fig. 2. (STRUCTURE, Pritchard et al. 2000). NWGR: NW Greenland, HS: Hudson Strait, FJLSVA: Franz Josef Land-Svalbard, EGR: E Greenland, WGR: W Greenland. Values in bold are significant

\begin{tabular}{|lcccccc|}
\hline & \multicolumn{7}{c|}{ Clusters suggested by STRUCTURE } \\
\cline { 2 - 6 } \cline { 5 - 7 } Sampling areas & NWGR & HS & FJL-SVA & EGR & WGR & \multirow{2}{*}{ N } \\
\hline NWGR & $\mathbf{0 . 6 1 1}$ & 0.097 & 0.069 & 0.035 & 0.188 & 72 \\
WGR & 0.068 & 0.155 & 0.056 & 0.068 & $\mathbf{0 . 6 5 4}$ & 33 \\
HS & 0.033 & $\mathbf{0 . 6 7 5}$ & 0.09 & 0.028 & 0.174 & 58 \\
EGR & 0.020 & 0.035 & 0.098 & $\mathbf{0 . 8 0 7}$ & 0.040 & 76 \\
SVA & 0.061 & 0.141 & $\mathbf{0 . 6 1 0}$ & 0.051 & 0.136 & 28 \\
FJL & 0.109 & 0.105 & $\mathbf{0 . 5 6 8}$ & 0.132 & 0.087 & 30 \\
\hline
\end{tabular}

\section{Estimation of historical and contemporary migration patterns (Objective 2)}

The analyses of migration patterns west of Greenland suggested that the historical and recent migration direction was predominantly from the Hudson Strait to W Greenland with a moderate average number of historical migrants per generation $(N m=2.48$; Fig. 3a). The equilibrium model (MIGRATE) suggested asymmetrical historical migration from NW to W

Given the harmonic mean of the effective population size from the 2 populations in terms of $\theta\left(4 N_{e} \mu\right.$, Fig. 3a), and using the $95 \%$ confidence intervals of $\theta$ and $F_{\mathrm{ST}}$ and an average microsatellite mutation rate of $5 \times 10^{-4}$ (Weber \& Wong 1993), the estimated divergence time started 4 to 18 generations ago. Assuming a generation time of about $15 \mathrm{yr}$, this corresponds to some time during the 1700 s to 1900 s.
Greenland, but this pattern was not reflected in the estimate of the recent direction, which indicated very little interchange between these 2 areas. Both historical and recent migration direction and average exchange of migrants per generation between the Hudson Strait and NW Greenland were balanced and small (Fig. 3a,b).

For the sub-populations east of Greenland (Fig. 3c), the historical migration direction went from E Green- 
West of Greenland

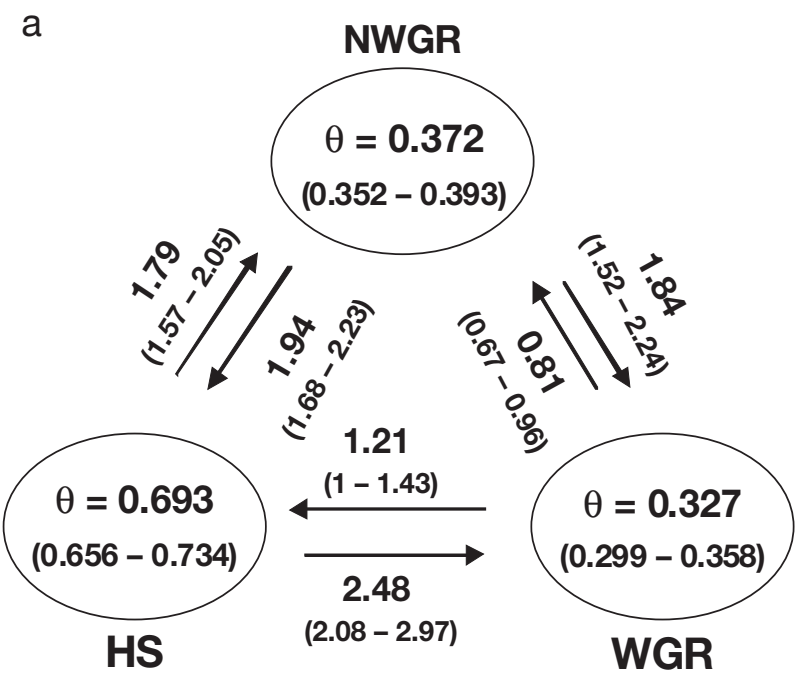

East of Greenland
C EGR

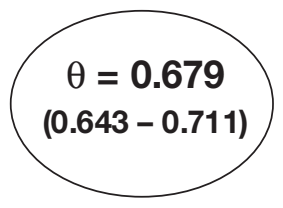

1.52

$(1.34-1.74)$

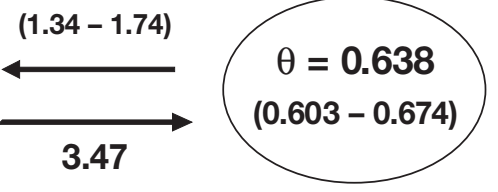

$(2.99-3.97)$ b

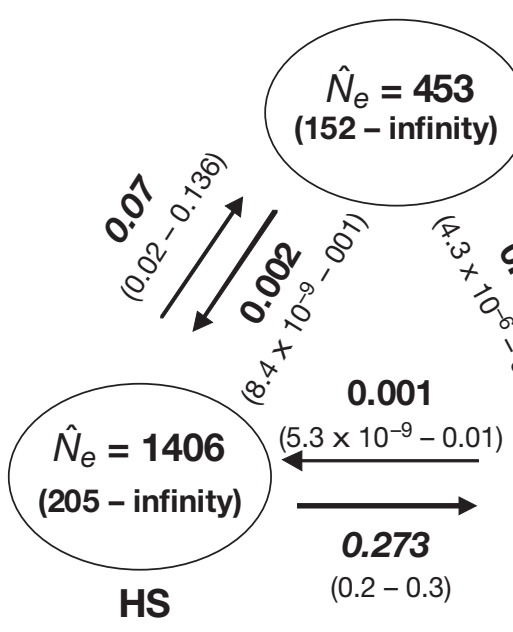

d EGR

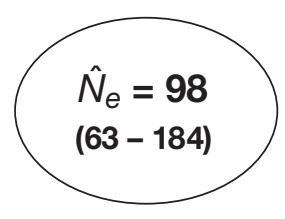

0.016

$\left(1.9 \times 10^{-5}-0.07\right)$

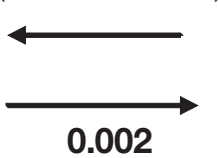

$\left(2.9 \times 10^{-7}-0.01\right)$
FJL-SVA

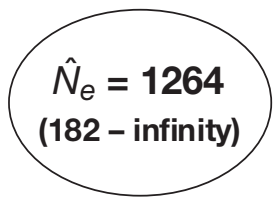

Fig. 3. Odobenus rosmarus rosmarus. Estimates (a) of the effective historical population size ( $\theta$ ) gene flow and migration directions (numbers and arrows) for the populations west of Greenland estimated in MIGRATE (Beerli 2006); (b) estimate of recent effective population size $\left(\hat{N}_{e}\right)$ using linkage disequilibrium (Waples 2006) and migration rate and directions for the populations west of Greenland estimated in BAYESASS (Wilson \& Rannala 2003); (c) results of the effective historical population size ( $\theta$ ) gene flow and migration directions (numbers and arrows) for the populations east of Greenland estimated; (d) estimate of recent $\hat{N}_{e}$ and migration rate and directions for the populations east of Greenland (WGR: W Greenland, NWGR: NW Greenland, HS: Hudson Strait, EGR: E Greenland, FJL-SVA: Franz Josef Land-Svalbard). Numbers in parentheses $=95 \%$ CI. Numbers in italics indicate proportions of migrants where data are considered to be informative. Means of $0.833(0.675-0.992$ [95\% CI]) for non-migrants and $0.032\left(1.58 \times 10^{-6}-0.160[95 \% \mathrm{CI}]\right)$ for migrants observed in the analysis of the 6 sampling locations indicated that the data did not contain sufficient information

land to Franz Josef Land-Svalbard. In contrast, the more recent estimates (Fig. 3d) reflected a symmetrical and low migration between the 2 areas.

Comparing migration directions between sub-populations west and east of Greenland, the historical migration direction went from NW Greenland to Franz Josef Land-Svalbard (Fig. 4a). Between NW and E Greenland (Fig. 4a), the historical migration was sym- metrical and lower. However, the more recent migration direction and rate was low and symmetrical (Fig. 4b) between NW and E Greenland and Franz Josef Land-Svalbard. In W Greenland, both the historical and contemporary methods suggested a migration direction going from E to W Greenland, while the direction was symmetrical between W Greenland and Franz Josef Land-Svalbard (Fig. 4c,d). A moderate 


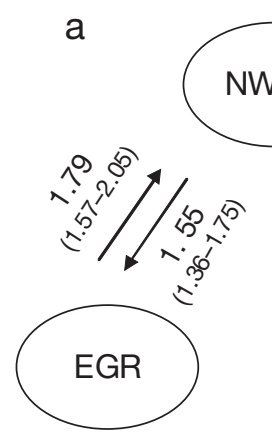

NWGR
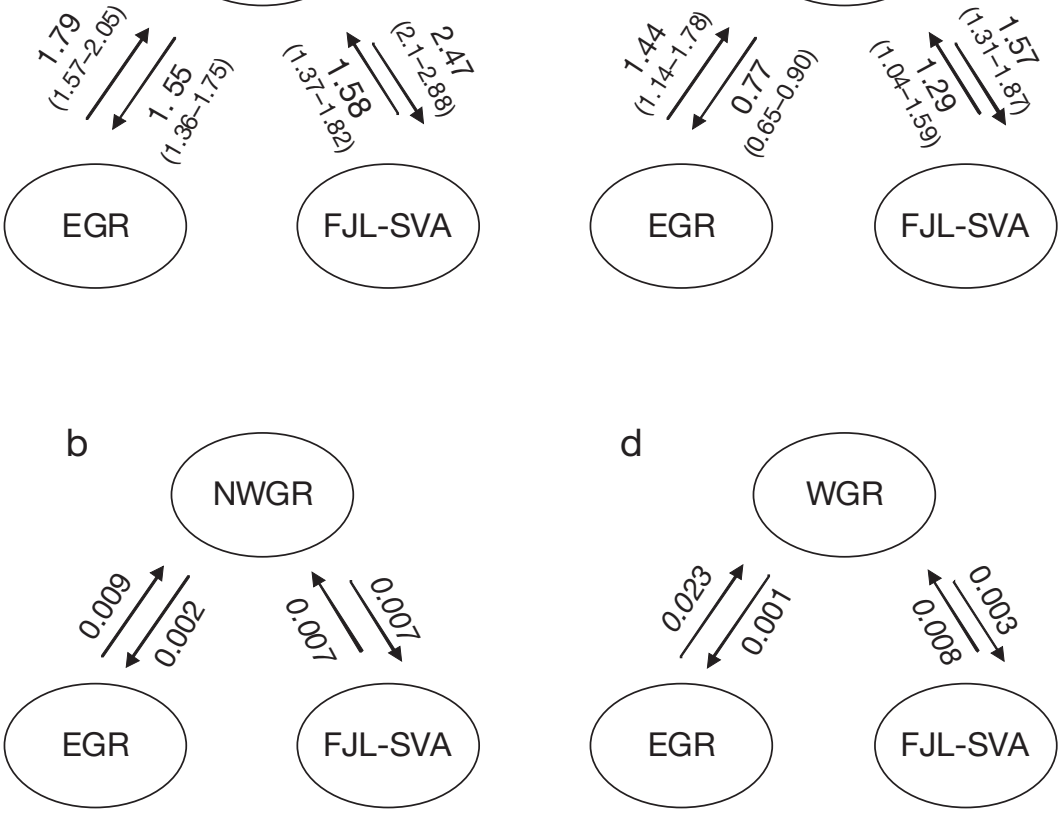
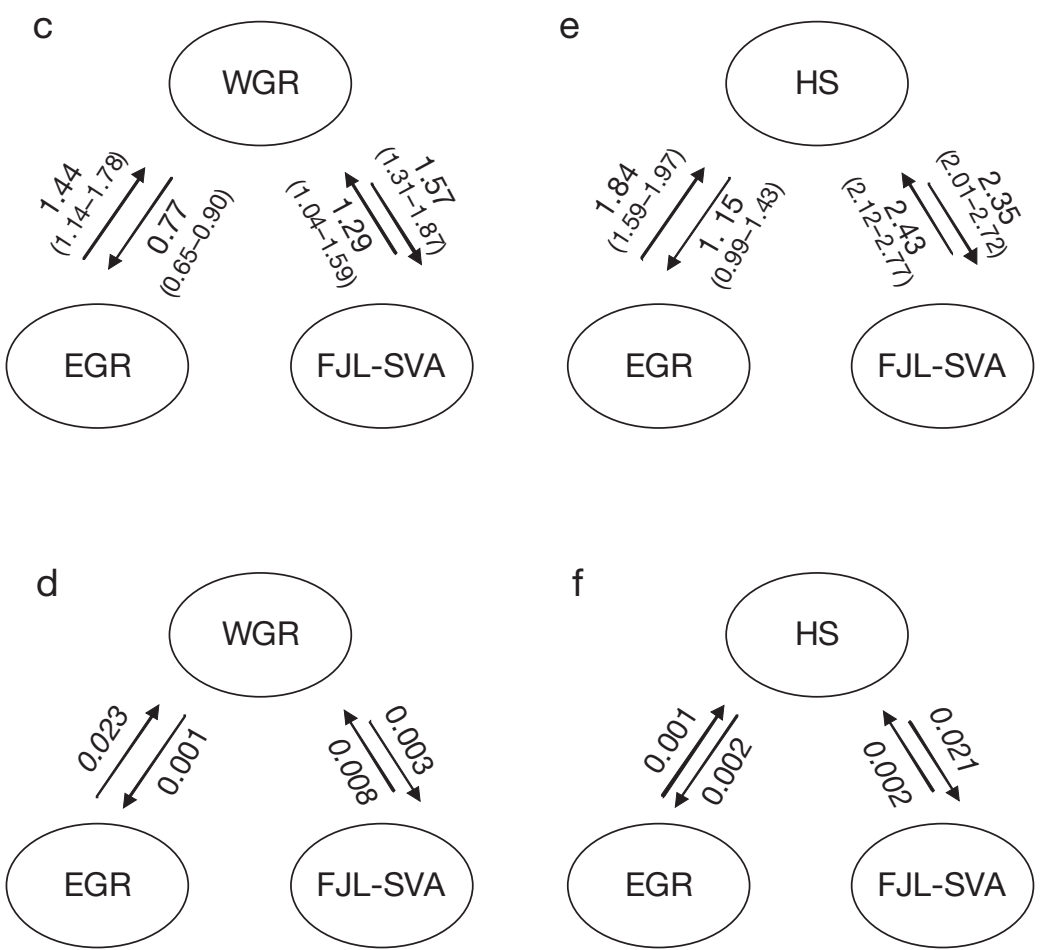

Fig. 4. Odobenus rosmarus rosmarus. (a) Results of the historical gene flow and migration directions (numbers and arrows) for the populations between NW Greenland (NWGR) and E Greenland (EGR), Franz Josef Land-Svalbard (FJL-SVA) estimated in MIGRATE (Beerli 2006); (b) recent migration rate and directions estimated in BAYESASS (Wilson \& Rannala 2003); (c) historical gene flow and migration directions between W Greenland (WGR) and EGR, FJL-SVA; (d) estimate of recent migration rate and directions; (e) historical gene flow and migration directions between Hudson Strait and EGR, FJL-SVA; (f) recent migration rate and directions. Numbers in parentheses $=95 \%$ CI. Numbers in italics indicate proportions of migrants where data are considered to be informative. Means of $0.833\left(0.675-0.992\right.$ [95\% CI]) for non-migrants and $0.032\left(1.58 \times 10^{-6}-0.160\right.$ [95\% CI]) for migrants observed in the analysis of the 6 sampling locations indicated that the data did not contain sufficient information

historical and symmetrical migration direction was estimated between the Hudson Strait and Franz Josef Land-Svalbard (Fig. 4e,f), but this was not reflected in the more recent estimate, where the migration rate was low between these 2 sub-populations. Between the Hudson Strait and E Greenland, both the historic and recent migration direction and rate were estimated to be symmetrical and low.

No significant correlation was observed between genetic and geographical distances among the walrus sub-populations when a Mantel test was implemented in ARLEQUIN (data not shown).

\section{Historical and recent estimates of effective population size (Objective 3)}

For the sub-populations west of Greenland, likelihood estimates of the historical effective population size in terms of $\theta$ decreased from 0.693 in the Hudson Strait to 0.372 in NW Greenland and 0.327 in W Greenland (Fig. 3a). The same pattern of relative effective size was found in the estimates of contemporary $\mathrm{N}_{\mathrm{e}}$ based on linkage disequilibrium (Fig. 3b).

The historical population sizes in the sub-populations east of Greenland were at comparable levels (Fig. 3c), while the contemporary $\mathrm{N}_{\mathrm{e}}$ estimate was an order of magnitude lower for the E Greenland sample $\left(\mathrm{N}_{\mathrm{e}}=98,95 \% \mathrm{CI}: 63-184\right)$ compared to the estimate for Franz Josef Land-Svalbard sample $\left(\mathrm{N}_{\mathrm{e}}=1264,95 \% \mathrm{CI}\right.$ : 182-infinity; Fig. 3d).

After application of the sequential Bonferroni correction, no indication of a bottleneck was detected in any of the walrus sub-populations (data not shown). The results of the simulations to test the performance of BOTTLENECK 1.2 give some insight to the power to detect bottlenecks. In the control runs, none of the populations showed indications of a bottleneck (data not shown). When the Wilcoxon test was used to test the 50 ind. from the populations with bottleneck $\mathrm{N}_{\mathrm{e}}=200,41$ of the 100 showed a significant heterozygote excess. Finally, only 8 of the 100 populations with a bottleneck of $\mathrm{N}_{\mathrm{e}}=$ 1000 showed significant heterozygote excess, just slightly more than would be expected by chance. 


\section{DISCUSSION}

\section{Estimation of the number of sub-populations (Objective 1)}

The genetic differences based on pairwise $F_{\mathrm{ST}}$ estimates (Table 3) suggested 5 sub-populations of Atlantic walruses: Hudson Strait, W, NW and E Greenland and Franz Josef Land-Svalbard. The significant $F_{\text {ST }}$ estimate observed between the Hudson Strait and W Greenland sub-populations was small and comparable to the level observed between Franz Josef Land and Svalbard, although the latter failed to reach statistical significance and has previously been shown to constitute 1 sub-population (Wiig et al. 1996, Andersen et al. 1998, Born et al. 2001). Furthermore, the Bayesian clustering analysis implemented in STRUCTURE confirmed the separation into 5 different gene pools, i.e. the analysis identified Hudson Strait and W Greenland as different gene pools, and Franz Josef Land and Svalbard as belonging to the same gene pool also with increasing numbers of clusters $(k)$. The identification of W, NW and E Greenland and Franz Josef Land-Svalbard sub-populations confirms previous studies (Andersen et al. 1998, Born et al. 2001), whereas the finding that walruses from the Hudson Strait differ genetically from walruses in the other areas is novel (Table 4, Fig. 2).

Genetic structure at a comparable geographical scale has been observed in other pinniped species with an affinity to terrestrial haul-out sites (Allen et al. 1995, Stanley et al. 1996, Goodman 1998, Slade et al. 1998, Wynen et al. 2000, Trujillo et al. 2004). These studies have been based on more traditional approaches, such as $F_{\mathrm{ST}}$ and analyses of molecular variance (AMOVA). This finding suggests that at least those pinnipeds that rely on regular access to haul-outs on land exhibit pronounced genetic population sub-structuring. This is probably related to their dependence on such haul-out sites, which may influence the social structure of the species.

The estimate of divergence time between the Hudson Strait and W Greenland suggests that they might have diverged some time during the 'Little Ice Age' (LIA). The LIA was a long, sustained cold period in the North Atlantic from 1300-1400 to 1900 (Grove 2001, Przybylak 2003). This period was characterised by particularly severe winters and an average temperature slightly cooler than in present-day Greenland (Dahl-Jensen et al. 1998, Przybylak 2003). During the LIA, glaciers advanced in Greenland, and the pack ice extended farther south (Reiter 2000). In the late 1500s, Atlantic walruses lived (and probably reproduced) in areas farther south than at present: Sable Island $\left(44^{\circ} \mathrm{N}\right)$ off Nova Scotia (J. Allen 1880, G. Allen 1930) and possibly the
Orkney Islands in Scotland (59 ${ }^{\circ} \mathrm{N}$; Ray 1960). The extended pack ice and the severe winters may have affected the distribution of walruses during the mating period by restricting and separating suitable wintering locations. Born et al. (2001) proposed that the walruses in the 3 areas to the west of Greenland belonged to the same ancestral population. Our results support their suggestion that the genetic divergence (based on both mitochondrial and microsatellite markers) between NW and W Greenland and walruses to the east of Greenland could be attributed to a separation caused by the existence of massive ice masses during the last glaciation period. However, intensive exploitation by commercial sealers and whalers during the 19th century (Born et al. 1995 and references therein) might have reduced the range of the species, adding to the geographical separation of the groups of walruses.

\section{Estimation of historical and contemporary migration patterns (Objective 2)}

\section{W Greenland}

It is not possible to compare the levels of historical and recent (contemporary) gene flow and dispersal rate directly. Gene flow is estimated in terms of effective number of migrants averaged over the coalescence time $\left(4 \mathrm{~N}_{\mathrm{e}}\right.$ generations), and the dispersal rate is the proportion of migrants between the populations over the past 2 to 3 generations (Austin et al. 2004). However, assuming that the sub-populations were at mutation-drift equilibrium over the geographical range, patterns of migration direction can be evaluated. Given the hypothesised historical counter-clockwise migration movement pattern of walruses in the Baffin Bay region (Freuchen 1921, Vibe 1950), the direction of migration captured by the genetic signal is expected to go from the Hudson Strait to W Greenland and maybe to NW Greenland. If this movement has been constant over a long period of time, we would expect the 2 different methods (i.e. MIGRATE and BAYESASS) to indicate similar patterns. Both historical and contemporary migration patterns imply that the Hudson Strait functions as a source for W Greenland, hence supporting the counter-clockwise movement of walruses in the area. The discrepancy observed between the estimates of magnitude of gene flow using the 2 approaches may have been caused by the fact that samples of walruses from all areas in the Baffin Bay region were not included in this study (e.g. eastern Ellesmere and Baffin Islands; cf. Born et al. 1995). In addition, the sample sizes analysed might not be representative of the entire population (Beerli 2004), and not all assumptions behind the different 
methods used (i.e. MIGRATE assumes a constant effective population size over several years) were met.

Apparently, walruses previously migrated from NW to W Greenland, but the more recent estimate (Fig. 3) suggests that this migration has ceased. Given the similar level of genetic differences between NW and W Greenland and between NW Greenland and the Hudson Strait, the estimated divergence time for both pairs (1700s to 1900s) coincides roughly with the 'Little Ice Age' as the event influencing genetic drift. We found no evidence that the migration pattern has changed over time between NW Greenland and the Hudson Strait.

The recently described performance problems (Faubet et al. 2007) observed in the algorithm used in BAYESASS (Wilson \& Rannala 2003) were shown to be related to violation of the underlying demographic model, the level of genetic differentiation and the number of individuals and loci in the analysis. The present study largely met the lower bound of the critical criteria observed for the above-mentioned suggested requirements, i.e. the walrus populations exchange migrants in a manner that is not much different from the Wright island model, $F_{\mathrm{ST}} \sim 0.05$, close to the sample size used by Faubet et al. (2007), and the number of loci used (11) was close to the suggested 15 loci (Faubet et al. 2007). Based on our study, we believe that the Hudson Strait, W and NW Greenland are genetically different sub-populations that are connected through migration and are diverging slowly.

\section{E Greenland}

The change in migration pattern observed in $\mathrm{E}$ Greenland may be reflected in the crude estimate of the time for divergence. Given the level of differentiation $\left(F_{\mathrm{ST}}=0.038,95 \%\right.$ CI 0.02-0.052), the time of divergence started around the 1400 s to 1800 s, likewise suggesting LIA as the probable event driving the separation of the sub-populations to the east (i.e. Franz Josef Land-Svalbard).

\section{Between W and E Greenland}

The analysis of migration direction and rate between W and E Greenland during a longer time span supported the earlier hypothesis of a common ancestral walrus population in the North Atlantic about the time of the end of the last Ice Age $12000 \mathrm{yr}$ ago (Born et al. 2001). This hypothesis is corroborated by the fossil finds of walruses on the Atlantic coast of North America, that indicate a northern limit of their Last Glacial Maximum (LGM) 'refuge' near Long Island (New
York, USA, ca. $43^{\circ} 57^{\prime}$ N) that advanced to the central Canadian Arctic by 9700 BP and to the Bay of Fundy (Nova Scotia, Canada, ca. $45^{\circ} 0^{\prime} \mathrm{N}$ ) by 7500 BP (Dyke et al. 1999). In the North Sea and Denmark, finds of 24000 to $31000 \mathrm{yr}$ old walrus fossils indicate that walruses were a 'Danish' faunal element during the last Ice Age (Møhl 1985). At that time, a huge ice sheet covered Scandinavia (e.g. Hughes et al. 1981), and walruses probably lived close to their northernmost border. However, in those areas of the North Atlantic where walruses lived during the LGM, there was no vast continental shelf. This reduction in the range of suitable walrus habitat in the western and eastern Atlantic, and likely also in walrus abundance, probably caused a 'bottleneck' effect that could explain the genetic differences between walruses to the west and to the east of Greenland (Andersen et al. 1998, Born et al. 2001). Furthermore, the dispersal between the populations would also be restricted as indicated by the recent migration/dispersal estimates in the present study, hence indicating that the more sedentary behaviour observed during the last century is reflected in the genetic make-up.

In Atlantic walruses, the patterns of isolation by distance depend on the geographical scale of interest. Andersen et al. (1998) did not detect isolation by distance among walruses in NW Greenland, E Greenland and Franz Josef Land-Svalbard. Including W Greenland in the isolation by distance analysis, Born et al. (2001) detected a significant isolation by distance pattern. In the present study, the Hudson Strait sample was included in the isolation by distance analysis together with the other 4 sub-populations. This inclusion increased the geographical distance between the sub-populations, which, together with the genetic divergence observed between areas, disrupted the significant isolation by distance pattern. This suggests that factors other than geographical distance may be just as important (for example the last Ice Age, $18000 \mathrm{yr}$ ago) as described for the southern elephant seal Mirounga leonina by Slade et al. (1998).

\section{Historical and recent estimates of effective population size (Objective 3)}

The difference between historical and recent effective population size observed in the E Greenland sample could be a result of heavy commercial exploitation in the late 19th and early 20th centuries (cf. Born et al. 1997). In the 1950s, walruses almost disappeared from eastern Greenland and Svalbard when regulations to protect them were introduced (Gjertz \& Wiig 1994, 1995, Born et al. 1997). However, the recent effective population size estimate might be biased downwards 
due to lack of proper identification of migrants from different sub-populations and low sample sizes, both factors that reduce the power of the LDNe method and generally led to wide confidence intervals for the point estimates.

No significant reduction in population size was detected in any of the sub-populations using both tests for bottlenecks. The $\mathrm{M}$ ratio test is regarded as a more informative test for the detections of more contemporary bottlenecks (between 125 and 500 generations or even more recent; Garza \& Williamson 2001) when (1) these have lasted for several generations, (2) the population has recovered demographically and (3) the prebottleneck population size was high or mutation rates were high (Williamson-Natesan 2005). If the bottleneck was more recent and less severe and pre-bottleneck population size was low or mutation rate was low, the test for heterozygosity excess would be more likely to identify a bottleneck (Williamson-Natesan 2005).

The simulation tests based on the demographic parameters for the Atlantic walrus and the observed genetic diversity at the 11 loci indicated that BOTTLENECK 1.2 (Piry et al. 1999) could detect a significant reduction in population size after 50 generations when the bottleneck size was $\mathrm{N}_{\mathrm{e}}=100$ or $\mathrm{N}_{\mathrm{e}}=200$, but not when $N_{e}=1000$. However, simulation results show that with bottleneck $\mathrm{N}_{\mathrm{e}}=200$, the power of the algorithm used in BOTTLENECK 1.2 is less than $50 \%$ for datasets comparable to those for the walrus. The bottleneck in the walrus sub-populations east of Greenland occurred in the 18th and 19th centuries ( 28 walrus generations) so one explanation could be that the reduction in size happened too recently to be detected or that $\mathrm{N}_{\mathrm{e}}$ has not been as low as suggested by the catch statistics (Born et al. 1997, Gjertz et al. 1998). According to this hypothesis, the walruses were not extirpated, but moved somewhere else or survived in more remote and less accessible areas (e.g. the northernmost parts of NE Greenland and Franz Josef Land). Another explanation could be that the underlying assumption of the mutation model does not fit the microsatellite loci used.

\section{Management implications for the walruses west of Greenland}

This study indicates that the role of Hudson Strait walruses as a source for walruses hunted on the wintering grounds in W Greenland has been constant over several centuries. The more sedentary behaviour suggested by Mansfield (1973) may not yet have resulted in a cease in the movements of some walruses from the Hudson Strait to W Greenland. Furthermore, the results indicate that during the LIA, the distribution of the sea ice probably restricted the movement of walruses and influenced their access to various foraging grounds so that the populations started to diverge into more isolated sub-populations.

This information is important for the management of the walruses. Differences in the genetic make-up of walruses from different geographical areas studied indicate that they represent sub-populations and should be managed separately. However, the study also indicated the existence of some contemporary migration between the putative sub-populations in the Baffin Bay area - a fact that must be considered when setting sustainable catch levels for the various areas. The indication that such connections have existed for several centuries might explain why the genetic variation observed in the W Greenland sample was at the same level as observed in the samples from the Hudson Strait and NW Greenland despite estimates of abundance in W Greenland only being in the low thousands (Witting \& Born 2005, NAMMCO 2006).

Walruses are completely protected in Svalbard and Franz Josef Land (cf. Gjertz \& Wiig 1994, Born et al. 1995) and are thought to be taken at sustainable levels in E Greenland (NAMMCO 2006). However, exploitation is believed to be the main limiting factor and is a threat to the Atlantic walrus in certain parts of Canada, including the stocks shared with NW Greenland and W Greenland (COSEWIC 2006, NAMMCO 2006, Stewart 2008). Walruses are still hunted for subsistence purposes in E, W and NW Greenland and the Hudson Strait (COSEWIC 2006, NAMMCO 2006, Stewart 2008). Until 2006, the catch of walruses in Greenland was not regulated by any quota system, whereas the catch of walruses in Canada has been regulated for decades by either individual bag limits or settlement/community quotas (COSEWIC 2006).

Although estimates of abundance in several of the areas occupied by sub-populations are inadequate, the estimates and qualified 'guesstimates' indicate that the different sub-populations of Atlantic walruses number only few hundreds to few thousands (Born et al. 1995, COSEWIC 2006, NAMMCO 2006). Given the uncertainty connected with the estimates of the effective population size $\left(\mathrm{N}_{\mathrm{e}}\right)$ in the present study and the lack of population estimates for most of the sub-populations, the $\mathrm{N}_{\mathrm{e}} / \mathrm{N}$ ratio was not estimated. However, this relationship could be a tool which management could employ in order to follow the importance of the removals on the survival of the sub-populations.

Walruses occur along the SE coast of Baffin Island (Born et al. 1995, Stewart 2008) vis-à-vis the W Greenland walrus grounds. Walruses on SE Baffin Island may well be connected to the W Greenland walruses as suggested by Born et al. (1994). The existence of this connection has been supported by recent satellite 
telemetry where walruses instrumented in W Greenland moved to SE Baffin Island during spring (Greenland Institute of Natural Resources and Danish National Environmental Research Institute unpubl. data). Hence, walruses exploited in W Greenland may be winter migrants from a sub-population that also occurs in SE Baffin.

Currently, the management of the shared populations of Atlantic walruses in Canada and Greenland is not formally coordinated. However, the fact that the W and NW Greenland sub-populations are shared calls for a coordinated management plan. An important part of such management is identification of sub-populations or management units. The present study is a contribution to identification of management units. However, efforts to determine the identity of sub-populations shared by Canada and Greenland continue.

Acknowledgements. This study was financed by the Commission for Scientific Research in Greenland (Copenhagen), the Danish Natural Science Foundation, the Greenland Institute of Natural Resources (Nuuk), the Research Council of Norway (NFFR grant no. 735.004). Special thanks to A. Christiansen for excellent assistance in the laboratory. The help of the Canadian and Greenland subsistence hunters and the Greenland Institute of Natural Resources, who collected the samples, is gratefully acknowledged. Samples from Svalbard and Franz Josef Land were collected when I.G. and Ø.W. were employed by the Norwegian Polar Institute. P. May and S. Suppa sub-sampled archival walrus tissue from Makivik Corporation's walrus meat diagnostic program, which tests for Trichinella sp. We thank C. Kapel (Royal Veterinary College, Copenhagen) for helping with the shipping of the Canadian samples to Copenhagen. R. Dietz kindly provided estimates of distance between various geographical areas. A. Gordon and M. Simard provided useful editorial comments. Finally, we thank 3 anonymous reviewers for comments that greatly improved the manuscript.

\section{LITERATURE CITED}

Aars J, Lunn NJ, Derocher AE (2006) Polar bears: Proc 14th Working Meeting of the IUCN/SSC Polar Bear Specialist Group, 20-24 June 2005, Seattle, Washington. Occas Pap IUCN SSC 32

Allen JA (1880) History of North American pinnipeds. US Geological and Geographical Survey of the Territories. Misc Publ No. 12

Allen GM (1930) The walrus in New England. J Mammal 11: 139-145

Allen PJ, Amos W, Pomeroy PP, Twiss D (1995) Microsatellite variation in grey seals (Halichoerus grypus) shows evidence of genetic differentiation between two British breeding colonies. Mol Ecol 4:653-662

- Alvarez-Flores CM, Heide-Jørgensen MP (2004) A risk assessment of the sustainability of the harvest of beluga Delphinapterus leucas (Pallas 1776) in West Greenland. ICES J Mar Sci 61:274-286

Andersen LW, Born EW (2000) Indications of two genetically different sub-populations of Atlantic walruses (Odobenus rosmarus rosmarus) in west and northwest Greenland. Can J Zool 78:1999-2009

Andersen LW, Born EW, Gjertz I, Wiig Ø, Holm LE, Bendixen C (1998) Population structure and gene flow of the Atlantic walrus (Odobenus rosmarus rosmarus) in the eastern Atlantic Arctic based on mitochondrial DNA and microsatellite variation. Mol Ecol 7:1323-1336

Anonymous (1995) Report of the ad hoc Working Group on Atlantic Walrus. In: North Atlantic Marine Mammal Commission (NAMMCO) Annual Report 1995. NAMMCO, Tromsø, p 101-119

Anonymous (2005) ANNEX 1 Report of the joint meeting of the NAMMCO Scientific Committee working group and the JCNB scientific working group on the population status of narwhal and beluga in the North Atlantic. In: North Atlantic Marine Mammal Commission (NAMMCO) Annual Report 2005. NAMMCO, Tromsø, p 219-251

Austin JD, Lougheed SC, Boag PT (2004) Controlling for the effects of history and nonequilibrium conditions in gene flow estimates in northern bullfrog (Rana catesbeiana) populations. Genetics 168:1491-1506

Balloux F (2001) EASYPOP (version 1.7): a computer program for population genetics simulations. J Hered 92:301-302

Beerli P (2004) Effect of unsampled populations on the population size and migration rates between sampled populations. Mol Ecol 13:827-836

> Beerli P (2006) Comparison of Bayesian and maximum-likelihood inference of population genetic parameters. Bioinformatics 22:341-345

> Beerli P, Felsenstein J (2001) Maximum likelihood estimation of a migration matrix and effective population sizes in $n$ subpopulations by using a coalescent approach. Proc Natl Acad Sci USA 98:4563-4568

Born EW (2001) Reproduction in female Atlantic walruses (Odobenus rosmarus rosmarus) from northwestern Greenland. J Zool (Lond) 255:165-174

Born EW (2003) Reproduction in male Atlantic walruses (Odobenus rosmarus rosmarus) from the North Water (N Baffin Bay). Mar Mamm Sci 19:819-831

Born EW, Böcher J (eds) (2001) The ecology of Greenland. Ilinniusiorfik, Nuuk

Born EW, Heide-Jørgensen MP, Davis RA (1994) The Atlantic walrus (Odobenus rosmarus rosmarus) in West Greenland. Medd Grønl Biosci 40:1-33

Born EW, Gjertz I, Reeves RR (1995) Population assessment of Atlantic walrus (Odobenus rosmarus rosmarus). Norsk Polarinst Medd 138

Born EW, Dietz R, Heide-Jørgensen MP, Knutsen LØ (1997) Historical and present distribution, abundance and exploitation of Atlantic walruses (Odobenus rosmarus rosmarus L) in eastern Greenland. Medd Grønl Biosci 46:1-70

$>$ Born EW, Andersen LW, Gjertz I, Wiig Ø (2001) A review of the genetic relationships of Atlantic walruses (Odobenus rosmarus rosmarus) east and west of Greenland. Polar Biol 24:713-718

Cornuet JM, Luikart G (1996) Description and power analysis of two tests for detecting recent population bottlenecks from allele frequency data. Genetics 144:2001-2014

COSEWIC (Committee on the Status of Endangered Wildlife in Canada) (2006) Assessment and update status report on the Atlantic walrus (Odobenus rosmarus rosmarus) in Canada COSEWIC, Ottawa. www.cosewic.gc.ca/eng/ sct7/index_e.cfm?\#rep

> Dahl-Jensen D, Mosegaard K, Gundestrup N, Clow CD, Johnsen SJ, Hansen AW, Balling N (1998) Past temperatures directly from the Greenland ice sheet. Science 282: 268-271 
Di Rienzo A, Peterson AC, Garza JC, Valdes AM, Slatkin M, Freimer NB (1994) Mutational processes of simplesequence repeat loci in human populations. Proc Natl Acad Sci USA 91:3166-3170

Dyke AS, Hooper J, Harington CR, Savelle JM (1999) The late Wisconsinan and Holocene record of walrus (Odobenus rosmarus) from North America: a review with new data from Arctic and Atlantic Canada. Arctic 52:160-181

Faubet P, Waples RS, Giaggiotti OE (2007) Evaluating the performance of a multilocus Bayesian method for the estimation of migration rates. Mol Ecol 16:1149-1166

Fay FH (1982) Ecology and biology of the Pacific walrus, Odobenus rosmarus divergens Illiger. North American Fauna Ser No. 74. US Dept Interior Fish Wildl Serv, Washington, DC

Fay FH, Ray GC, Kibal'chich AA (1984) Time and location of mating and associated behaviour of the Pacific walrus Odobenus rosmarus divergens Illiger. In: Fay $\mathrm{FH}_{\text {, }}$ Fedoseev, GA (eds) Soviet-American cooperative research on marine mammals. Vol 1, Pinnipeds. NOAA Tech Rep NMFS 12, Washington, DC, p 89-99

Fischbach AS, Jay CV, Jackson JV, Andersen LW, Sage GK, Talbot SL (2008) Molecular method for determining sex of walruses. J Wildl Manag 72:1808-1812

Freuchen P (1921) Om hvalrossens forekomst og vandringer ved Grønlands vestkyst (Distribution and migration of walruses along the western coast of Greenland). Vid Medd Dansk Natur F København 72:237-249 (Translated: Fish Res Board Can Translation Ser 2383)

Garza JC, Williamson EG (2001) Detection of reduction in population size using data from microsatellite loci. Mol Ecol 10:305-318

Gjertz I, Wiig $\varnothing ~(1994)$ Past and present distribution of walruses in Svalbard. Arctic 47:34-42

Gjertz I, Wiig $\varnothing$ (1995) The number of walruses (Odobenus rosmarus) in Svalbard in summer. Polar Biol 15: 527-530

Gjertz I, Wiig Ø, Øritsland NA (1998) Backcalculation of original population size for walruses Odobenus rosmarus in Franz Josef Land. Wildl Biol 4:223-230

Goodman SJ (1998) Patterns of extensive genetic differentiation and variation among European harbor seals (Phoca vitulina vitulina) revealed using microsatellite DNA polymorphism. Mol Biol Evol 15:104-118

Goudet J (1995) FSTAT 2.9.3.1: a computer program to calculate F statistics. J Hered 86:485-486

- Grove JM (2001) The initiation of the 'Little Ice Age' in regions round the North Atlantic. Clim Change 48:53-82

Guo SW, Thompson EA (1992) Performing the exact test for Hardy-Weinberg proportion for multiple alleles. Biometrics 48:361-372

Hartl DL, Clark AG (1997) Principles of population genetics. 3rd edn. Sinauer Associates, Sunderland, MA

Hill WG (1981) Estimation of effective population size from data on linkage disequilibrium. Genet Res 38:209-216

Hughes TJ, Denton GH, Andersen BG, Schilling DH, Fastook JL, Lingle CS (1981) The last great ice sheets: a global view. In: Denton GH, Hughes TJ (eds) The last great ice sheets. John Wiley \& Sons, New York, p 275-318

Lydersen C, Aars J, Kovacs K (2008) Estimating the number of walruses in Svalbard from aerial surveys and behavioural data from satellite telemetry. Arctic 61:119-128

Mansfield AW (1973) The Atlantic walrus Odobenus rosmarus rosmarus in Canada and Greenland. IUCN Publ New Ser Suppl Pap 39:69-79
Milligan B (1992) Plant DNA isolation. In: Hoelzel H (ed) Molecular genetic analysis of populations: a practical approach. IRL Press, Oxford, p 59-88

Møhl U (1985) The walrus, Odobenus rosmarus (L.), as a Danish faunal element during the Weichsel Ice Age. Bull Geol Soc Den 34:83-85

NAMMCO (North Atlantic Marine Mammal Commission) (1995) Report of the third meeting of the Scientific Committee. In: NAMMCO annual report 1995, NAMMCO, Tromsø, p 71-127

NAMMCO (2006) NAMMCO annual report 2005. NAMMCO, Tromsø

Nei M, Maruyama T, Chakraborty R (1975) The bottleneck effect and genetic variability in populations. Evolution 29:1-10

Paetkau D, Slade R, Burdens M, Estoup A (2004) Genetic assignment methods for direct, real-time estimation of migration rates: a simulation-based exploration of accuracy and power. Mol Ecol 13:55-65

Piry S, Luikart G, Cornuet JM (1999) BOTTLENECK - a computer program for detecting recent reductions in the effective population size using allele frequency data. J Hered 90:502-503

Piry S, Alapetite A, Cornuet JM, Paetkau D, Baudouin L, Estoup A (2004) GeneClass2: a software for genetic assignment and first-generation migrant detection. J Hered 95:536-539

Pritchard JK, Stephens M, Donnelly P (2000) Inference of population structure using multilocus genotype data. Genetics 155:945-959

Przybylak R (2003) The climate of the Arctic. Kluwer Academic Publishers, Dordrecht

Ramstad KM, Woody CA, Sage K, Allendorf FW (2004) Founding events influence genetic population structure of sockeye salmon (Oncorhynchus nerka) in Lake Clark, Alaska. Mol Ecol 13:277-290

Rannala B, Mountain J (1997) Detecting immigration by using multilocus genotypes. Proc Natl Acad Sci USA 94: 9197-9201

Ray CE (1960) Trichecodon huxlei (Mammalia: Odobenidae) in the Pleistocene of southeastern United States. Bull Mus Comp Zool Harv Coll 122:129-142

Raymond M, Rousset F (1995) GENEPOP ver. 3.2: a population genetics software for exact tests and ecumenicism. J Hered 86:248-249

> Reiter P (2000) From Shakespeare to Defoe: malaria in England in the Little Ice Age. Emerg Infect Dis 6:1-11

- Rice WR (1989) Analyzing tables of statistical tests. Evolution 43:223-225

Schneider S, Roessli D, Excoffier L (2000) ARLEQUIN, v 2.0: a software for population genetics data analysis. Genetics and Biometry Laboratory, University of Geneva

> Sjare B, Stirling I (1996) The breeding behavior of Atlantic walruses, Odobenus rosmarus rosmarus, in the Canadian High Arctic. Can J Zool 74:897-911

Slade RW, Moritz C, Hoelzel AR, Burton HR (1998) Molecular population genetics of the southern elephant seal (Mirunga leonina). Genetics 149:1945-1957

Stanley HF, Casey S, Carnahan JM, Goodman S, Harwood J, Wayne RK (1996) Worldwide patterns of mitochondrial DNA differentiation in the harbor seal (Phoca vitulina). Mol Biol Evol 13:368-382

Stewart REA (2008) Redefining walrus stocks in Canada. Arctic 61:292-308

- Trujillo RG, Loughlin TR, Gemmel NJ, Patton JC, Bickham JW (2004) Variation in microsatellites and mtDNA across the range of the Steller sea lion Eumetopias jubatus. J Mammal 85:338-346 
Vibe C (1950) The marine mammals and the marine fauna in the Thule District (Northwest Greenland) with observations on the ice conditions in 1939-41. Medd Gronl 150:1-115

Waples RS (2006) A bias correction for estimates of effective population size based on linkage disequilibrium at unlinked gene loci. Conserv Genet 7:167-184

Waples RS, Do C (2008) $L D N E$ : a program for estimating effective population size from data on linkage disequilibrium. Mol Ecol Resour 8:753-756

Weber JL, Wong C (1993) Mutation of human short tandem repeats. Hum Mol Genet 2:1123-1128

Weir BS (1996) Genetic data analysis, 2nd edn. Sinauer, Sunderland, MA

Weir BS, Cockerham CC (1984) Estimating F-statistics for the analysis of population structure. Evolution 38:1358-1370

Editorial responsibility: Helene Marsh,

Townsville, Queensland, Australia
Wiig Ø, Gjertz I, Griffiths D (1996) Migration of walruses (Odobenus rosmarus) in the Svalbard and Franz Josef Land area. J Zool (Lond) 238:769-784

Williamson-Natesan EG (2005) Comparison of methods for detecting bottlenecks from microsatellite loci. Conserv Genet 6:551-562

Wilson GA, Rannala B (2003) Bayesian inference of recent migration rates using multilocus genotypes. Genetics 163:1177-1191

Witting LW, Born EW (2005) An assessment of Greenland walrus populations. ICES J Mar Sci 62:266-284

Wynen LP, Goldsworthy SD, Guinet C, Bester MN and others (2000) Postsealing genetic variation and population structure of two species of fur seal (Arctocephalus gazella and A. tropicalis). Mol Ecol 9:299-314

Submitted: March 15, 2008; Accepted: October 3, 2009

Proofs received from author(s): November 30, 2009 